AQ: 4

\section{Heterogeneous firm-level responses to the US 2018 tariff announcement}

\author{
Yafeng Qin and Zikai Yang
} College of Business, Massey University, Albany, New Zealand, and Min Bai

\author{
School of Accounting, Finance and Economics, Waikato Management School, \\ University of Waikato, Hamilton, New Zealand
}

Heterogeneous firm-level responses

Received 17 August 2020 Revised 25 November 2020 Accepted 6 December 2020

\begin{abstract}
Purpose - This study examines the impact of the $\$ 60$ billion tariff announcement of the US government on the Chinese exporting firms. In particular, it focuses on the firms whose revenues are highly dependent on the US economy.

Design/methodology/approach - This study uses an experimental analysis and the event study methodology. The sample includes firms listed in mainland China and Hong Kong Stock Exchanges that have the highest revenues from exporting to the USA. The data are obtained from China Stock Market and Accounting Research (CSMAR) and DataStream.

Findings - The authors find that the tariff announcement has significantly negative impacts on stock performance both before and after the announcement, and the impacts are heterogeneous across all sample firms. For A shares listed in Mainland China, firms with more revenues from the US experience greater price drops on the announcement day, regardless of being in the targeted industry or not. But such finding is absent from $\mathrm{H}$ shares listed in Hong Kong. The authors also find that for all the firms, greater pricing power can alleviate the impacts of the tariff announcement.

Research limitations/implications - The results provide implications to investors, policymakers and regulators on the further US-China cooperation in the future.

Originality/value - This is the first study documenting the heterogeneity of the impact of the tariff announcement and thus contributes to the prosperous studies on the varied firm-level responses in the Chinese stock market, and to the burgeoning literature by filling the gap of the financial market responses to the protectionist policy announcement.
\end{abstract}

Keywords Heterogeneous responses, Tariff announcement, US-China trade war

Paper type Research paper

On March 22, 2018, Donald Trump, the 45th president of the United States, signed the presidential memorandum to impose the tariff on up to 60 billion worth of Chinese imports, targeting the ten hightech and R\&D-demanding industries in the "Made in China 2025" plan. Relied upon the Section 301 of the US Trade Act of 1974, Trump justified the implementation of the tariff sanction as a response to China's unfair trade practices and the theft of American intellectual property over the years. Issuance of the presidential memorandum marked the official launch of what many described as the Sino-US trade war, triggering a sequence of tit-for-tat trade protectionist measures between two of the largest economies in the world.

\section{Introduction}

Although the motivation behind the enforcement of tariff sanction is to reduce the stubborn US trade deficit with China and to suppress China's burgeoning economy, the theory builds upon an outdated assumption that international trades chiefly concentrate on the transaction

\footnotetext{
JEL Classification - F10, G12, G14, O24
}

Declarations of interest: none

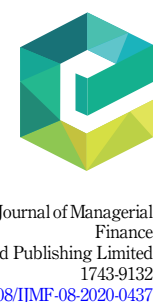

DOI 10.1108/IJMF-08-2020-0437 
of final goods. However, a revolutionary development in communication and transport along with diminishing cross-border trade barriers over the years enables the integration of nations into a global supply chain. Nowadays, the production process of a commodity can be easily broken up into several specific tasks, being outsourced to different countries according to their comparative advantages. While the tariff hike reduces the competitiveness of Chinese exporters in the US market, it also increases the cost of inputs imported from China, inducing collateral damages to American industries.

Research is conducted to capture the economic rents generated from government regulations, helping policymakers in subsequent decision-making, for example, environmental regulations (Zhao et al., 2018), financial innovation regulations (Yang and He, 2018) and share pledging regulations (Wang and Chou, 2018). Plenty of studies have examined the exposure to trade liberalist policies on the stock market. Empirical evidence shows that in an efficient and rational stock market, the impact of an unanticipated event will be instantly capitalized in stock prices (Mackinlay, 1997).

Recently, Crowley et al. (2018) test the abnormal stock performances of Chinese solar panel companies attributable to the European Union's import restraints regarding the anticompetitive price settings of Chinese solar panel exporters. The results are in line with Melitz (2003) theory that larger or more export-oriented companies incur higher losses in stock return when the counterparty imposes protectionist policy instruments. Moreover, the firm ownership and the stock market in which the firm is listed also help to explain the heterogeneity in the degree of abnormal stock returns across firms. The author finds out that state-owned enterprises (SOEs) are less responsive to policy shocks compared to private-owned enterprises. In the meantime, the announcement of trade restriction has a more significant negative influence on US-listed stock than companies listed in mainland China and Hong Kong.

In addition, Lenway et al. (1990) employ the modified market model to assess the economic rent and wealth losses of steel firms attributable to the imposition and rescission of the import relief in the US steel industry from 1969 to 1982. Two types of the trade barriers are drawn into the discussion: the trigger price mechanism (TPM) as price control and the voluntary export restraint (VER) as a quantitative restriction. The result of the event study shows that the whole steel industry does capture significant economic rents from the import protection regardless of what type of control is implemented, but individual firms experience unequal wealth gain upon the relief. A further cross-sectional analysis corroborates that the benefits from protection vary with the type of firms, firms' market shares, their profitability and their financial leverage status.

Our research studies the influences of the initiation of the Sino-US trade war on stock market performances of Chinese exporters. To be specific, the event we focus on is the issuance of the presidential memorandum by the Trump administration on March 22. Due to the time difference between China and the United States, the event date would be the next trading day, March 23, for the Chinese stock market. Although prior to the announcement, the United States had already imposed several rounds of safeguard tariffs on solar panels, washing machines, steels and aluminum. None of these tariffs is specifically against China. Generally, Chinese stock investors are unaware of the timing, duration and magnitude of the sanction, making the issuance of the presidential memorandum an extraordinary subject for the event study.

Along the lines of our research, a study by Liebman and Tomlin (2008) examines the perception of US stock traders to the retaliatory threat granted by the World Trade Organization in response to the safeguard tariff imposed by the Bush administration on steel products in March 2002. In the process of the dispute settlement, the author selects five events of interest that signal a different possibility of retaliation. Empirical results show that the targeted American firms react negatively to the events that induce a higher likelihood of retaliation but react positively to the termination of the safeguards. In the intra-industry 
analysis, the author finds out that stocks with higher export dependency on the European Union, faster profitability growth and less R\&D spending suffer more losses facing retaliatory threats.

The trade war is still going on at the time of writing, while studies have already been conducted to examine its influences on different levels. Huang et al. (2018) employ the event study to investigate the stock market reaction to the unilateral initiation of the trade dispute by the United States against China on March 22, 2018, considering the direct and indirect exposures of American firms to trades with China. The authors find that American companies with higher trade exposure to China, either as buyers or sellers, experience lower stock returns, weaker bond performances and a higher probability of default in the three-day event window. Interestingly, a similar pattern is detected for the stock performances of the US firms that are not directly engaged in trade with China but have upstream suppliers that are exposed to the Sino-US trade war, probably due to the tariff-induced increase in input prices.

Unlike the study of Huang et al. (2018), we examine the impact of the official launch of the trade war between the United States and China on stock performances. Their work, nevertheless, focuses on the role of the direct trade exposure and the supply chain linkage on amplifying the influences of the tariff hike on the US stock market. Our research instead

AQ: 8 contributes to the prosperous studies on the varied firm-level responses in the Chinese stock market to the tariff announcement, which we should look from two different angles. Firstly, we exploit this unique event to detect the interrelation of protectionist policy shocks and abnormal stock returns, shedding light on how the financial market perceives and digests new information contained in the trade restriction announcement. Secondly, the unexpected launch of the trade disputes between the United States and China also provides opportunities to gauge the influences of exposure to trade policy uncertainty and the threat of retaliation measures on stock performances. By selecting four samples with different criteria, we can differentiate the significance of tariff hike across stock markets. Moreover, the cross-sectional analysis provides evidence for the intra-industry effects of the protectionist policy announcement, specifying the types of Chinese exporting firms most likely to incur financial losses.

Besides the general impact of the tariff announcement on stock performances, we are also interested in the cross-sectional analysis of the heterogeneous firm-level responses to the event. We define the abnormal return at the event date as the principal regressor, and four intervals of cumulative abnormal return before and after the event date as the complementary regressors. Based on the data from CSMAR and DataStream, we construct several independent variables for each stock in our samples: (1) whether the firm is within the targeted sector, (2) trade exposure to the United States, (3) extent of control by the state and (4) pricing power.

The results of multivariate regression analysis provide significant evidence for the dependency of abnormal stock return on firm-specific characteristics, while the significance of coefficients varies across samples. For stocks listed in Shanghai and Shenzhen Stock Exchanges, more revenues from exporting to the USA, either measured by the absolute value or by the relative percentage of the firms' total operational revenues, are associated with lower abnormal returns around the event date. Such impact is the same between firms that are from the targeted industries of the tariff announcement and firms that are not from the targeted industry. However, such finding is absent from the $\mathrm{H}$ shares listed in Hong Kong Stock Exchange. We also find that firms with greater pricing powers are less affected by the announcement. This finding is prevalent among all our sample firms.

Our study contributes to the burgeoning literature by filling the gap of the financial market responses to the protectionist policy announcement. Firstly, we employ this exogenous event to examine how shareholders react to the tariff sanction, which significantly lifts the cost for the exporting company. The tariff announcement on March 22 is not an isolated event. Instead, it marks the official launch of the trade war between two of the largest
Heterogeneous firm-level responses 
economies in the world and triggers a sequence of retaliatory measures by the Chinese and US governments. Thus, we are able to detect how investors in the Chinese stock market perceive and digest the increased exposure to trade policy uncertainty and the threat of retaliation. In addition, the multivariate regression analysis distinguishes the intra-industry effects of the tariff hike on Chinese exporters with different characteristics.

The paper proceeds as follows. Section 2 provides the background of the event study. Section 3 introduces research design and statistical analysis. Section 4 describes data and methodology. Section 5 presents result and analysis, and Section 6 concludes.

\section{Event studies in strategic management and hypothesis development}

While stock market event studies are frequently used to test the effects of trade liberalization, they have rarely been employed to examine trade restriction or protectionist trade measures on either protected countries or the counterparty. Exceptions include Hughes et al. (1997), who confirm that both the US consumers and the US producers of semi-conductors benefit from the US trade protectionist moves against Japan. Hartigan et al. (1986) argue that the extent of benefits derived from administered protection is limited and is highly conditional on the internal characteristics of each firm.

Our research builds upon abundant prior studies in the event study literature. Empirical evidence shows that in an efficient and rational stock market, the impact of an unanticipated event will be instantly capitalized in stock prices (Mackinlay, 1997). Accordingly, event studies using financial market data are confirmed useful in measuring the influence of various shocks and are extensively applied in the research process. Miyajima and Yafeh (2007) analyze the extent and sensitivity of firm anomalous performances during Japan's banking crisis from 1995 to 2000. Wagner et al. (2017) examine the influence of Donald Trump's unanticipated election on stock prices due to the change in expectation about future tax rates. Gumanti et al. (2018) test how airline crashes cause abnormal returns and trading volume fluctuations in the travel and leisure industry.

Unlike other events that only affect specific industries, the official launch of the trade war between the United States and China causes ripple effects throughout the whole economy, especially for those firms that trade with the United States. Below are the key events before and after the issuance of the presidential memorandum that possibly has influences on the stock performances within our event window:

January 23, 2018: President Trump imposed the tariff on solar panels and washing machines that are manufactured in other countries in order to protect domestic manufacturers from foreign competition. Although the additional tariff is not specifically against China, as the world leader in solar panel production and also the largest exporter of washing machines to the United States, China incurs the most considerable losses.

March 1, 2018: President Trump declared his plan to slap the tariff on steel and aluminum imports. Meanwhile, Trump wrote in his tweet that "Trade wars are good and easy to win."

March 8, 2018: After citing Section 232 of the Trade Expansion Act of 1962, President Trump signed the official order to impose the 25 and $10 \%$ tariff on steel and aluminum, respectively. In the following weeks, the European Union, Canada, Mexico, Argentina, Australia, South Korea and Brazil were exempted from the order, but not China.

March 22, 2018: Under Section 301 of the Trade Act of 1974, President Trump signed the presidential memorandum, imposing a safeguard tariff on $\$ 50$ billion worth of Chinese imports and asking the US trade representatives to come up with the detailed list of goods that are subject to the tariff hike in 15 days

March 22 2018: A few hours later, the Ministry of Commerce of the People's Republic of China proposed to counterattack by imposing a retaliatory tariff of $15 \%-25 \%$ on a list of 128 American goods including pork, soybeans, airplanes, cars, aluminum (25\%) as well as nuts, fruit and steel piping $(15 \%)$. 
While the dividend discount model suggests that the stock price of a listed firm depends on the net present value of its future dividend payment, a tariff hike, which raises the cost and reduces the expected profitability of Chinese exporting firms, should put downward pressure on their firm values. As a result, if the stock traders do not entirely anticipate the tariff announcement, a significantly negative abnormal return is expected to be detected upon the event date. Then we have our main hypothesis as below:

H1. The announcement of tariff sanctions significantly affects the stock return of Chinese exporting firms.

President Trump asked the trade representative Robert Lighthizer to come up with a detailed list of goods that are subject to the tariff hike within 15 days after the issuance of the presidential memorandum. On the same day, Robert Lighthizer outlined in front of the US Senate Committee on Finance, ten industries that he thought should be on the list. These industries are mainly mentioned in the "Made in China 2025" project that the Chinese government is eager to dominate. The targeted sectors include advanced information technology, automated machine tools and robotics, aerospace and aeronautics equipment, maritime equipment and high-tech shipping, new-energy vehicles equipment, modern rail transport equipment, power equipment, agricultural equipment, new materials, biopharma and advanced medical products. Since the detailed list was not given at the event date, we manually match the firms in our sample with these ten sectors, generating a dummy variable that is equal to one if the firm is within these sectors and is equal to zero if not. The firms that are within the targeted industries are expected to have lower abnormal returns than firms that are not involved around the event date. In turn, we have the following hypothesis:

H2. The impact of tariff announcement on firms that are on the tariff list is greater than the impact on firms that are not on the tariff list.

Besides, we explore other factors that could drive the cross-sectional variation in the impact of tariff announcement on firms such as the firms' dependencies on the USA. For exporting firms, the proportion of their revenue from the USA in their total operating revenue should be an appropriate measure for their export dependencies on the USA. The official launch of the trade dispute between the United States and China on March 22, 2018, brings downward pressure on the psychological expectation of stock traders on those firms that depend heavily on exports to the United States. As the investors are afraid of the escalating tension and the upcoming tit-for-tat trade sanctions between the two parties, Chinese companies that have a higher percentage of the revenue from the USA in their total operating revenue are expected to incur lower abnormal return than the others [1]. Therefore, our third hypothesis is:

H3. The impact of tariff announcement on firms whose operation is more dependent on the United States is greater than the impact on firms that are less dependent.

Another factor that is also important is the pricing power of the companies. The pricing power is a desirable trait for exporting companies, enabling them to raise the price of their products in the foreign market without much loss in sales. If an export company produces goods that have close substitutes in the foreign market, it has to bear the additional tariff cost by itself due to its high price elasticity of demand, thus reducing its future profits. However, if an export company produces differentiated goods with significant pricing power, it can pass the tax incidence to foreign consumers by raising the price of products without severe losses of competitiveness in the market. As a result, the negative impacts of the tariff sanction on these firms with a low-price elasticity of demand are limited. The research conducted by Pan et al. (2018) shows that pricing power is a significant contributor to the firm value, shaping the volatility and growth of cash flows favorably. Hence, our last hypothesis is: 
H4. The impact of tariff sanctions on Chinese exporting firms is greater when the firms have weaker pricing power.

\section{Experimental design}

The data we use are from the publicly listed companies in the Shanghai Stock Exchange, the Shenzhen Stock Exchange and the Hong Kong Stock Exchange. In order to comprehensively examine the impact of the tariff announcement on Chinese exporting firms, we employed four samples of data with different selection criteria for the analysis. The first sample is the top 100 A shares ranked according to the ratio of the revenue generated from the USA in 2016 to the total operating revenue that year. A shares are stock shares that denominated in Chinese yuan and traded in the Shanghai and Shenzhen Stock Exchange. The second sample is the top $100 \mathrm{H}$ shares ranked according to the same ratio, providing additional analysis of the impact of the trade war on a different stock market. $\mathrm{H}$ share companies are incorporated in mainland China but listed on the Hong Kong Stock Exchange. They are also subject to the tariff imposed by the US government, just like A share companies. The third and the fourth samples, which we refer to as Sample 3 and Sample 4, are the top 100 A shares and H shares ranked according to the value of revenue generated from the USA in 2016, further validating the results of the previous analysis with different sample selection criteria [2]. In the following section of results and analysis, we will focus on interpreting the outputs of the first two samples, whereas the last two samples are only employed for the robustness test. The individual stock data and market data of stocks listed in Shanghai and Shenzhen Stock Exchange are retrieved from the China Stock Market and Accounting Research (CSMAR) database. The data of stocks listed in the Hong Kong Stock Exchange are downloaded from the DataStream.

To evaluate the different extent of the impact of the tariff announcement on firms with different firm-level characteristics, we define abnormal return at the event date as the primary dependent variable in the cross-sectional analysis. At the same time, four intervals of the cumulative abnormal return in the event window are regressed with independent variables to detect their correlations before and after the event. We use three different data sources to generate our independent variables. The first data source is the research report published by China International Capital Corporation (CICC), which is one of China's top investment banking company. The report ranks the three different samples in our study and tracks their export status. For each stock in our sample, we retrieve its trade data from the report. Other firm-level trading and accounting data are collected from the CSMAR database for A shares and DataStream for H shares, and corresponding to our hypotheses developed in the previous session, we construct the following independent variables for the analysis.

"LIST" is a dummy variable of whether the stock is within the ten targeted sectors on which the United States is about to impose a tariff. This variable is created by manually matching the industries registered in the stock exchange to which each firm belongs to with the ten industries announced by the US trade representative Robert Lighthizer on March 22, 2018. The variable "USRP" is the percentage of each company's revenue from the United States in its total operating revenue in 2016, and the variable "USR" is the exact value of each company's revenue from the United States in 2016. These two variables measure the export dependency of Chinese firms in the United States. Intuitively, companies that are more dependent on the revenue from the United States should incur more substantial losses on firm value once the tariff is imposed. We also build up to two interaction terms "LIST*USRP" and "LIST*USR," which are the product of two independent variables. These two interaction terms capture the relationship of the trade exposure to the United States with the influence of the tariff announcement for those stocks within the targeted industries. The coefficients of these two interaction terms are expected to share the same signs as the coefficients of "USRP" and "USR," but with greater significances. 
To measure the pricing power or market power of the firm, we follow Pan et al. (2018) to construct the Lerner Index "LI" calculated as sales less cost of goods and selling, general and administrative expenses, scaled by sales. As pricing power is defined as the ability of a firm to set a price above the marginal cost and earn a positive profit, the higher the index, the greater the firm's ability to set the price and earn stable profit, and the smaller the impact of the tariff announcement on the firm's performance.

Besides, we also construct the control variables that may affect the tariff impact across the firms. The first factor that needs to be controlled is firm size "MV," generated as the mean value of daily market capitalization, which is the product of shares issued multiplied by daily closing price in the past six months before the event. In general, large companies tend to be more diversified and thus may be less affected by the tariff announcement compared with small firms.

The second control is the extent of control by the Chinese government on each listed firm. We calculate this measure "SSP" as the percentage of each firm's state shares in its total number of shares. SOEs currently account for a significant part of the Chinese stock market. Firms with a significant amount of state shares enjoy favorable credit rating position and consequently are more accessible to bank loans, especially from state-owned banks. On the other hand, if a state-controlled enterprise is severely underperformed due to exogenous shocks like the tariff sanction, it will probably be bailed out by the government through subsidized packages. These advantages in the procurement of funds could pull the company through the economic downturn and exogenous shocks. As a result, an increase in the percentage of the state shares in total shares should be associated with less impact from the tariff announcement.

Compared to newly listed stocks, firms that have listed for years are supposed to have more experiences in dealing with price crashes under an exogenous shock. Countermeasures include making official announcements to clarify that the impact of the exogenous event on the firm is limited, helping to calm down investors and to prevent heavy selling of stocks. If the slump is out of control, the firm should apply to the stock exchange for a suspension to mitigate the losses in time. In order to differentiate stocks that are listed in the same year, we use the number of months for which the firms are listed in the stock exchange, "MONTH," as another control variable in the regression. Experienced firms are expected to be less impacted than newly listed firms by the tariff announcement.

Previous studies generate contradictory results for the relation between stock volatility and the expected stock return. Under traditional asset pricing models assuming that all investors are risk-averse, Merton (1987) believes that companies with higher idiosyncratic risk require a higher stock return to compensate individual stock traders and agents for holding a portfolio that is not perfectly diversified. However, Ang et al. (2006) found out directly opposite results that stocks with higher firm-specific risks have a lower stock return on average. Moreover, the prospect theory suggests that stock traders tend to be risk-averse when they incur losses and risk-seeking when they capture gains. Differentiating stocks according to their past performances in the Chinese stock market, Qu et al. (2019) detect a positive volatility-return relation among firms with a positive abnormal return and a negative volatility-return relation among firms with a negative abnormal return. In our analysis, we use the standard deviation of the individual stock return in the estimation window "VO" to measure the volatility of different stocks as another control variable.

Liquidity is another factor that could potentially affect that tariff impact and should be controlled for. Stocks with high liquidity attract investors with low trading cost and facilitation of exit, but at the same time, are vulnerable to price crash facing exogenous shocks. In this study, we use "TOR," the mean of the daily turnover ratio in the past six 
months before the event, as a proxy of the stock liquidity for each firm. More liquid firms are supposed to have a lower abnormal return around the event date.

We also control for the firms' R\&D intensity. Liebman and Tomlin (2008) analyze the response of shareholders to the threat of retaliatory tariffs authorized by the World Trade Organization (WTO) and find that R\&D intensive firms are more insulated from the threat of retaliation, as shareholders may be less responsive to conditions in the export market if they view the firm's welfare from a more long-term perspective. We use the logarithm of the R\&D expenditure, "LnRD," to control for such an effect.

We follow the standard approach in event studies to measure the abnormal return of Chinese exporting firms listed in Shanghai, Shenzhen and Hong Kong Stock Exchange when the US government announced safeguard tariff imposition on Chinese imports on March 22, 2018. To adjust for the systematic risk and compute the abnormal stock return generated by the event, the first step is to model the relationship between individual stock return and market stock return. In this case, we use a simple one-factor market model:

where

$$
R_{i \tau}=\alpha_{i}+\beta_{i} R_{m \tau}+\varepsilon_{i \tau}
$$

$R_{i \tau}$ is the actual stock return for firm $i$ at date $\tau$;

$R_{m \tau}$ is the return for market portfolio at date $\tau$ (for A shares, the daily market return with cash dividend reinvested (total value weighted) downloaded from CSMAR is used as the market return; For H shares, daily return calculated using Heng Seng China Enterprise Price Index downloaded from DataStream is used as the market proxy);

$\varepsilon_{i \tau}$ is the disturbance term with zero mean;

$\alpha_{i}$ is constant;

$\beta_{i}$ is the systematic risk of firm $i$.

We estimate equation (1) for each firm in our sample using daily stock return with cash dividend reinvested from 260 trading days to 6 trading days before the issuance of the presidential memorandum, that is, $(\tau-260)$ to $(\tau-6)$, where $\tau$ represents the event date. Based on the market model parameter estimates $\widehat{\alpha}_{i}$ and $\widehat{\beta}_{i}$, we can calculate the abnormal return by subtracting the expected return from the actual stock return:

$$
\widehat{\mathrm{AR}}_{i \tau}=R_{i \tau}-\widehat{\alpha}_{i}-\widehat{\beta}_{i} R_{m \tau}
$$

To get an overall inference for the abnormal return in certain time intervals, the cumulative abnormal return (CAR) is computed through the aggregation of the abnormal return along time dimension:

$$
\widehat{\mathrm{CAR}}\left(\tau_{1}, \tau_{2}\right)=\sum_{\tau=\tau_{1}}^{\tau_{2}} \widehat{\mathrm{AR}}_{i \tau}
$$

As it takes time for the stock traders to absorb the new information released at the event date and there might be information leakage prior to the event date, we construct four intervals for the cumulative abnormal return pre- and post-event: $\widehat{\mathrm{CAR}}(-5,-3), \widehat{\mathrm{CAR}}(-3,-1)$, $\widehat{\mathrm{CAR}}(+1,+3)$ and $\widehat{\mathrm{CAR}}(+3,+5)$.

For each day in our event windows, we take the average of the abnormal return for each stock to construct the average abnormal return (AAR) for each date $\tau$. This measure gives us a sense of whether the announcement, on average, induces an increase or decrease in equity values across firms at date $\tau$. 


$$
\mathrm{AAR}_{\tau}=\overline{\mathrm{AR}}_{\tau}=\frac{1}{N} \sum_{\mathrm{i}=1}^{N} \widehat{\mathrm{AR}}_{i \tau}
$$

The variance of the average abnormal return for date $\tau$ is

$$
\operatorname{var}\left(\mathrm{AAR}_{\tau}\right)=\frac{1}{N^{2}} \sum_{i=1}^{N} \sigma_{\varepsilon_{i}}^{2}
$$

In the same way, the average cumulative abnormal return can be calculated as:

$$
\operatorname{CAAR}\left(\tau_{1}, \tau_{2}\right)=\overline{\operatorname{CAR}}\left(\tau_{1}, \tau_{2}\right)=\frac{1}{N} \sum_{i=1}^{N} \widehat{\operatorname{CAR}}_{\tau}\left(\tau_{1}, \tau_{2}\right)
$$

The second part of our research is to test the heterogeneous firm-level response to the tariff announcement. As a primary focus of the study, the abnormal return of firms at the event date is adopted as the main dependent variable in the cross-sectional analysis. In addition, four intervals of cumulative abnormal returns are used as dependent variables to detect disparate influences on stock returns of firms with distinctive characteristics before and after the event. For the univariate regression, each dependent variable is regressed by one independent variable at a time. One of the key assumptions in univariate test is that all other factors affecting $y$, which are captured by the disturbance term $u$, are not correlated with $x$, but this is unrealistic in most of the cases. By explicitly controlling for other factors that affect the explained variables, we could easily interpret the result, ceteris paribus. We also perform the multivariate regressions as follows, with vector $X$ including all the control variables.

$$
\begin{aligned}
& \operatorname{AR}(0)=\beta_{0}+\beta_{1} \mathrm{LIST}+\beta_{2} \mathrm{USRP}+\beta_{3} \mathrm{LIST} * \mathrm{USRP}+\beta_{5} \mathrm{LI}+\beta_{i} X+u \\
& \operatorname{AR}(0)=\beta_{0}+\beta_{1} \mathrm{LIST}+\beta_{2} \mathrm{USR}+\beta_{3} \mathrm{LIST} * \mathrm{USR}++\beta_{5} \mathrm{LI}+\beta_{i} X+u
\end{aligned}
$$

\section{Statistical analysis}

We evaluate the unexpectedness and new information contained in the exogenous event using data downloaded from the Baidu Index and Google Trends. Previous studies from Da et al. (2011) show that the searching frequency in search engines like Google effectively

F1 captures the attention of investors. Figure 1 plots the searching frequencies in Baidu, the largest search engine in China, using the keywords "Trade War" and "Tariff" in Chinese around the event date. The figure indicates that the frequency of searching keywords mentioned above skyrockets on the event date, actively supporting the vital presumption that Chinese investors are unaware of the upcoming trade war between China and the United States. As Google is blocked in mainland China but is useable in Hong Kong, we also plot the

F2 public interest in Google of the term "Trade War" and "Tariff" (Figure 2). Figure 2 provides substantial support for the unexpectedness of the trade war to investors out of mainland China as the public interest over the term "trade war" reached its summit at the event date. However, there appears to be a pre-search of the term "tariff" prior to the issuance of the presidential memorandum, possibly due to the tariff imposition and exemptions on steel and aluminum imports at the beginning of March. Moreover, the plummet of the CSI 300 Index by $2.87 \%$ and the Hang Seng China Enterprises Price Index by $2.41 \%$ on March 23, 2018, suggests that the unilateral initiation of the trade war by the United States is not completely anticipated in both China and Hong Kong stock markets.

We tabulate the descriptive statistics of the abnormal stock return for our event window in

T1-4 Tables 1-4. As we can see, both A shares and H shares included in our sample suffer from 


\section{IJMF}

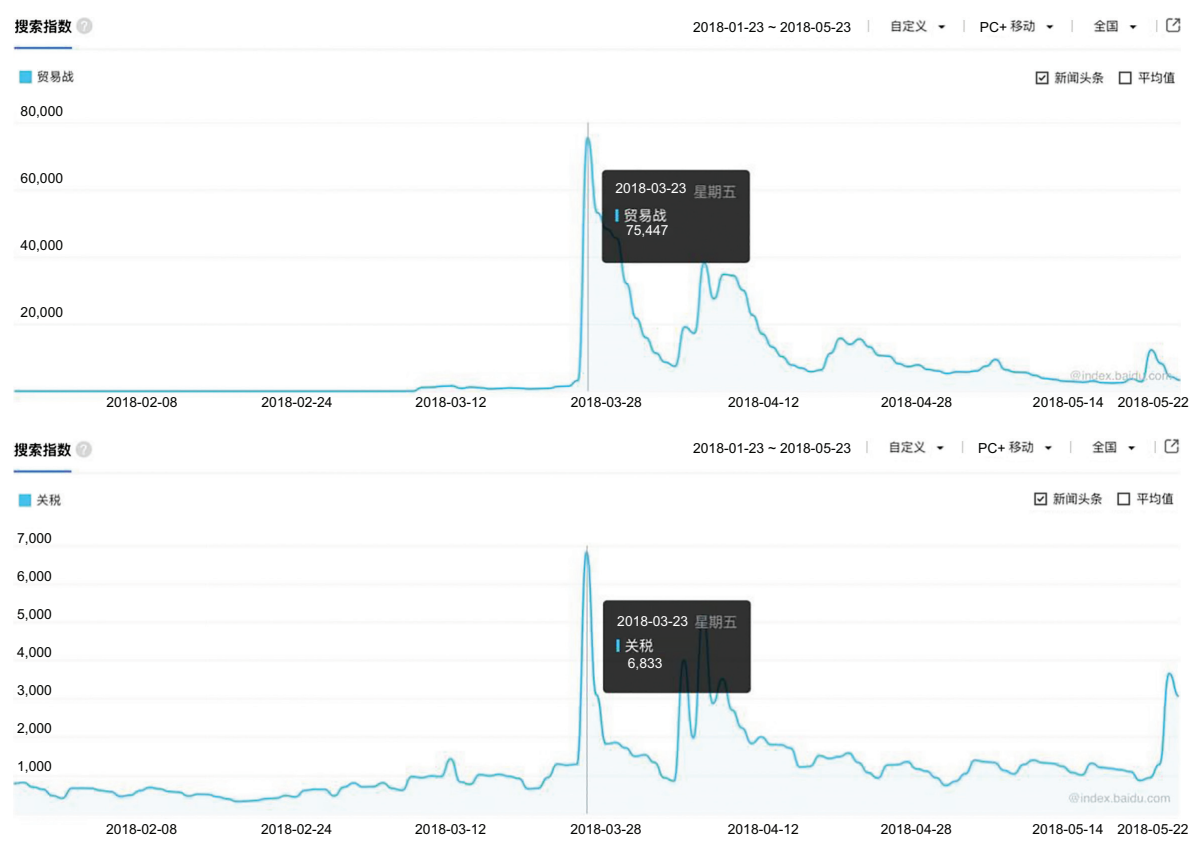

Figure 1.

Searching frequencies of "trade war" and "tariff" in Baidu

\section{Figure 2.}

Searching frequencies of "trade war" and "tariff" in Google
Note(s): $y$-axis plots the searching frequency of the "Trade War" and "Tariff" in Baidu while a value of 100 indicates the peak popularity of the term. The data from two months prior to the event to two months after the event are used to construct the figure

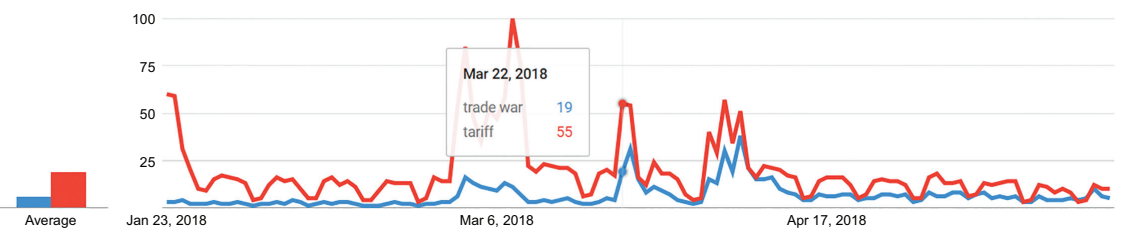

Note(s): $y$-axis plots the public interest of the "Trade War" and "Tariff" in Google while a value of 100 indicates the peak popularity of the term. The data from two months prior to the event to two months after the event are used to construct the figure

significantly negative stock returns at the event date. To be specific, the top $100 \mathrm{~A}$ shares and H shares ranked by USRP have a negative return of 1.38 and $1.32 \%$, respectively, at day zero, while the top $100 \mathrm{H}$ shares ranked by USR experience a 1.46\% negative abnormal return. Surprisingly, the top 100 A shares ranked by USR have only $0.28 \%$ negative return on average at the event date, probably because the investors are aware of the upcoming tariff announcement pre-event. As shown by Figure 3, the successive drop of the abnormal return in Sample 3 before the announcement date provides evidence for the potential information leakage in the stock market. 


\begin{tabular}{|c|c|c|c|c|c|c|}
\hline Day & Mean/t-stats & $p$-value & Median & Minimum & Maximum & Standard deviation \\
\hline-5 & $0.0067 * * *$ & 0.0017 & 0.0054 & -0.0266 & 0.1113 & 0.0211 \\
\hline-4 & 0.0000 & 0.4952 & -0.003 & -0.0586 & 0.0975 & 0.0202 \\
\hline-3 & $(-0.0016)$ & 0.2415 & -0.0023 & -0.0585 & 0.0971 & 0.0241 \\
\hline-2 & 0.0016 & 0.2462 & -0.0002 & -0.0606 & 0.1101 & 0.0247 \\
\hline-1 & $0.0068^{* * * *}$ & 0.0016 & 0.0051 & -0.0392 & 0.1095 & 0.0217 \\
\hline 0 & $-0.0138^{* * * *}$ & 0.0000 & -0.0215 & -0.0626 & 0.1798 & 0.0345 \\
\hline 1 & $0.0131^{* * * *}$ & 0.0000 & 0.0141 & -0.0517 & 0.0655 & 0.0212 \\
\hline 2 & $0.0096^{* * *}$ & 0.0000 & 0.0088 & -0.0281 & 0.0732 & 0.0179 \\
\hline 3 & $0.0063^{* * *}$ & 0.0033 & 0.0087 & -0.0815 & 0.0995 & 0.0235 \\
\hline 4 & $(-0.0032)^{*}$ & 0.0859 & -0.0042 & -0.0709 & 0.0825 & 0.0206 \\
\hline 5 & $0.0109 * * *$ & 0.0000 & 0.0064 & -0.0399 & 0.0913 & 0.0227 \\
\hline \multicolumn{7}{|c|}{$\begin{array}{l}\text { Note(s): This table presents the descriptive statistics and the results of significance tests of abnormal stock } \\
\text { return for Sample } 1 \text {. The sample contains } 99 \text { companies that are incorporated in mainland China and are listed } \\
\text { in Shanghai and Shenzhen Stock Exchanges as ranked on the basis of the percentage of the revenue from the } \\
\text { United States in total operating revenue in } 2016 \text { (Wang and Li, 2018). All the figures are rounded to four decimal } \\
\text { places. The symbols *, ** and *** denote the significance at the } 10 \%, 5 \% \text { and } 1 \% \text { significance level, } \\
\text { respectively }\end{array}$} \\
\hline
\end{tabular}
firm-level responses

Note(s): This table presents the descriptive statistics and the results of significance tests of abnormal stock return for Sample 1. The sample contains 99 companies that are incorporated in mainland China and are listed in Shanghai and Shenzhen Stock Exchanges as ranked on the basis of the percentage of the revenue from the United States in total operating revenue in 2016 (Wang and Li, 2018). All the figures are rounded to four decimal places. The symbols *, ** and *** denote the significance at the $10 \%, 5 \%$ and $1 \%$ significance level,

respectively

Table 1. and significance tests of abnormal stock return for Sample 1

\begin{tabular}{lcccccc}
\hline Day & Mean/t-stats & $p$-value & Median & Minimum & Maximum & Standard deviation \\
\hline-5 & -0.0007 & 0.4061 & -0.0009 & -0.1157 & 0.0774 & 0.0286 \\
-4 & -0.0001 & 0.4848 & -0.0003 & -0.0958 & 0.2214 & 0.0356 \\
-3 & 0.0013 & 0.3329 & 0.0007 & -0.0745 & 0.0737 & 0.0219 \\
-2 & $-0.0078^{* * *}$ & 0.0049 & 0.0002 & -0.2334 & 0.0524 & 0.0358 \\
-1 & $-0.0070^{* *}$ & 0.0109 & -0.0026 & -0.117 & 0.0627 & 0.0245 \\
0 & $-0.0132^{* * *}$ & 0.0000 & -0.0108 & -0.1091 & 0.0385 & 0.0219 \\
1 & -0.0007 & 0.4132 & -0.0011 & -0.0764 & 0.0708 & 0.024 \\
2 & $0.0080^{* * *}$ & 0.0043 & 0.0027 & -0.0727 & 0.1027 & 0.03 \\
3 & $-0.005^{* *}$ & 0.0498 & 0.0006 & -0.0924 & 0.061 & 0.0264 \\
4 & $0.0041^{*}$ & 0.0905 & 0.0012 & -0.0654 & 0.088 & 0.0263 \\
5 & -0.0001 & 0.4820 & 0 & -0.0083 & 0.0058 & 0.002
\end{tabular}

Note(s): This table presents the descriptive statistics and the results of significance tests of abnormal stock return for Sample 2. The sample contains 99 companies that are incorporated in mainland China but are listed in Hongkong Stock Exchange as ranked on the basis of the percentage of the revenue from the United States in total operating revenue in 2016 (Wang and $\mathrm{Li}, 2018$ ). All the figures are rounded to four decimal places. The symbol $*$, ** and $* * *$ denote the significance at the $10 \%, 5 \%$ and $1 \%$ significance level, respectively

Table 2.

Descriptive statistics and significance tests of abnormal stock return for Sample 2

Comparing to USR (the exact value), USRP (the percentage) appears to have superiority in measuring the trade exposure of Chinese firms to the United States. As a result, the first two samples are more susceptible to the tariff announcement than the third one as we expected. For Sample 1, the average abnormal return at seven- out of eleven-day event window is significantly different from zero, while only five days in the event window at which the average abnormal return is significantly different from zero for Sample 2. The third sample shows even lower significance in average abnormal returns than the first two samples. For Sample 4, the average abnormal return at six- out of the eleven-day event window is significantly different from zero.

In addition to the analysis of the impact of tariff announcement on stock return at the event date, we are also interested on how potential information leakage causes abnormal return pre-event and how investors perceive and process new information post-event. The 


\section{IJMF}

\begin{tabular}{lllcccc}
\hline Day & Mean/t-stats & $p$-value & Median & Minimum & Maximum & Standard deviation \\
\hline-5 & -0.0002 & 0.4614 & 0 & -0.0437 & 0.068 & 0.0166 \\
-4 & $-0.0055^{* * *}$ & 0.0024 & -0.0045 & -0.0602 & 0.0431 & 0.0159 \\
-3 & $-0.0041^{* *}$ & 0.0169 & -0.0061 & -0.0501 & 0.074 & 0.0166 \\
-2 & 0.0008 & 0.3427 & 0.0006 & -0.0912 & 0.1101 & 0.019 \\
-1 & $0.0026^{*}$ & 0.0929 & 0.0002 & -0.0904 & 0.1093 & 0.0235 \\
0 & $-0.0028^{*}$ & 0.0764 & -0.0067 & -0.0626 & 0.1186 & 0.0294 \\
1 & -0.0007 & 0.3562 & 0.0012 & -0.0811 & 0.0831 & 0.0261 \\
2 & -0.0008 & 0.3459 & -0.002 & -0.0666 & 0.0757 & 0.0182 \\
3 & $-0.0041^{* *}$ & 0.0166 & -0.0003 & -0.0656 & 0.0382 & 0.0181 \\
4 & -0.0007 & 0.3545 & -0.0015 & -0.0487 & 0.0387 & 0.0173 \\
5 & -0.0004 & 0.4211 & -0.0063 & -0.0269 & 0.0892 & 0.0191
\end{tabular}

Table 3.

Descriptive statistics and significance tests of abnormal stock return for Sample 3
Note(s): This table presents the descriptive statistics and the results of significance tests of abnormal stock return for Sample 3. The sample contains 100 companies that are incorporated in mainland China and are listed in Shanghai and Shenzhen Stock Exchanges as ranked on the basis of the value of the revenue from the United States in 2016 (Wang and Li, 2018). All the figures are rounded to four decimal places. The symbol *, ** and *** denote the significance at the $10 \%, 5 \%$ and $1 \%$ significance level, respectively

\begin{tabular}{lcccccc}
\hline Day & Mean/t-stats & $p$-value & Median & Minimum & Maximum & Standard deviation \\
\hline-5 & -0.0016 & 0.2432 & -0.004 & -0.0522 & 0.0739 & 0.0224 \\
-4 & -0.0006 & 0.4042 & -0.0007 & -0.0533 & 0.0837 & 0.0231 \\
-3 & 0.0012 & 0.3018 & -0.0018 & -0.1275 & 0.1094 & 0.0271 \\
-2 & $-0.0053^{* * *}$ & 0.0102 & 0.0007 & -0.2334 & 0.0646 & 0.0334 \\
-1 & $-0.0058^{* * * *}$ & 0.0057 & -0.0024 & -0.066 & 0.0627 & 0.0204 \\
0 & $-0.0146^{* * * *}$ & 0.0000 & -0.0124 & -0.1092 & 0.0385 & 0.0216 \\
1 & $0.0035^{*}$ & 0.0629 & 0.0014 & -0.0764 & 0.0708 & 0.0236 \\
2 & $0.0071^{* * *}$ & 0.0009 & 0.003 & -0.0727 & 0.1027 & 0.0282 \\
3 & $-0.0074^{* * *}$ & 0.0006 & -0.0023 & -0.0924 & 0.061 & 0.0276 \\
4 & 0.0042 & 0.3455 & 0.0012 & -0.0597 & 0.073 & 0.0225 \\
5 & -0.0004 & 0.4253 & -0.0005 & -0.0083 & 0.0034 & 0.0016
\end{tabular}

Table 4.

Descriptive statistics and significance tests of abnormal stock return for Sample 4
Note(s): This table presents the descriptive statistics and the results of significance tests of abnormal stock return for Sample 4. The sample contains 99 companies that are incorporated in mainland China but are listed in Hongkong Stock Exchange as ranked on the basis of the value of the revenue from the United States in 2016 (Wang and Li, 2018). All the figures are rounded to four decimal places. The symbol *, ** and *** denote the significance at the $10 \%, 5 \%$ and $1 \%$ significance level, respectively

descriptive statistics, along with the result of the significance test, are presented in Table 5.

For Sample 1, the average cumulative abnormal return after the event is statistically significant and positive, while for Sample 2, the average cumulative abnormal return from the day -3 to day -1 is statistically significant and negative. On the other hand, the average cumulative abnormal return from the day -5 to day -3 for Sample 3 is statistically significant and negative at a 10\% significance level. For Sample 4, the average cumulative abnormal return from the day -3 to day -1 is significantly different and negative, just like Sample 2.

Figure 4 plots the cumulative average abnormal return for the top 100 A shares ranked by USRP, providing graphical evidence for the overall influence of the announcement within the event window. The trend of cumulative average abnormal return from the day -5 to day -1 seems like natural fluctuation in the stock market, without any significant variation in the abnormal return. However, there is a plunge of the cumulative abnormal return at the event 


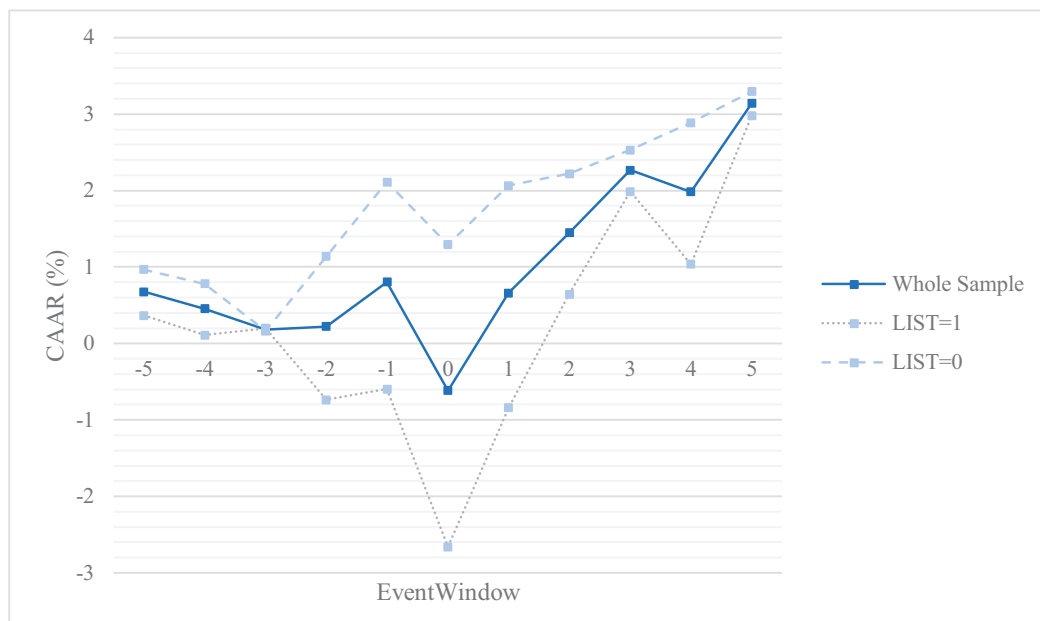

Note(s): The solid line plots the CAAR of the whole sample. The dotted line plots the CAAR of firms that are within ten target industries of the safeguard tariff. The dash line plots the CAAR of firms that are not subject to the tariff imposition. The scale for the $y$-axis is in percentage
Heterogeneous firm-level responses

Figure 3. Cumulative average abnormal return for Sample 1

\begin{tabular}{|c|c|c|c|c|c|c|}
\hline Variables & Mean & Median & Minimum & Maximum & $\begin{array}{l}\text { Standard } \\
\text { deviation }\end{array}$ & $\begin{array}{l}\% \text { Of firms with } \\
\text { negative return }\end{array}$ \\
\hline \multicolumn{7}{|c|}{ Panel A. Top 100 A shares ranked by USRP (Sample 1) } \\
\hline $\mathrm{CAR}(-5,-3)$ & 0.0018 & -0.0026 & -0.1220 & 0.1211 & 0.0355 & $46.46 \%$ \\
\hline $\mathrm{CAR}(-3,-1)$ & 0.0041 & 0.0027 & -0.0768 & 0.1789 & 0.0371 & $39.39 \%$ \\
\hline $\mathrm{CAR}(+1,+3)$ & $0.0285^{* * * * *}$ & 0.0269 & -0.0754 & 0.1474 & 0.0402 & $20.20 \%$ \\
\hline $\mathrm{CAR}(+3,+5)$ & $0.0142^{* *}$ & 0.0128 & -0.1067 & 0.1572 & 0.0382 & $27.27 \%$ \\
\hline \multicolumn{7}{|c|}{ Panel B. Top 100 H shares ranked by USRP (Sample 2) } \\
\hline $\mathrm{CAR}(-5,-3)$ & 0.0005 & 0.0016 & -0.1751 & 0.2000 & 0.0468 & $49.49 \%$ \\
\hline $\mathrm{CAR}(-3,-1)$ & $-0.0135 * *$ & -0.0081 & -0.2661 & 0.0822 & 0.0495 & $58.59 \%$ \\
\hline $\mathrm{CAR}(+1,+3)$ & 0.0023 & 0.0020 & -0.1164 & 0.1344 & 0.0430 & $45.45 \%$ \\
\hline $\mathrm{CAR}(+3,+5)$ & -0.0011 & -0.0020 & -0.0732 & 0.1081 & 0.0306 & $54.55 \%$ \\
\hline \multicolumn{7}{|c|}{ Panel C. Top 100 A shares ranked by USR (Sample 3) } \\
\hline $\mathrm{CAR}(-5,-3)$ & $-0.0098 * *$ & -0.0116 & -0.0822 & 0.1177 & 0.0318 & $72.00 \%$ \\
\hline $\mathrm{CAR}(-3,-1)$ & 0.0012 & 0.0000 & -0.0687 & 0.1789 & 0.0345 & $48.00 \%$ \\
\hline $\mathrm{CAR}(+1,+3)$ & -0.0054 & 0.0004 & -0.1323 & 0.1381 & 0.0449 & $46.00 \%$ \\
\hline $\operatorname{CAR}(+3,+5)$ & -0.0053 & -0.0055 & -0.0941 & 0.0628 & 0.0295 & $54.00 \%$ \\
\hline \multicolumn{7}{|c|}{ Panel D. Top 100 H shares ranked by USR (Sample 4) } \\
\hline $\mathrm{CAR}(-5,-3)$ & -0.0010 & -0.0078 & -0.0610 & 0.1966 & 0.0390 & $58.59 \%$ \\
\hline $\mathrm{CAR}(-3,-1)$ & $-0.0099 * *$ & -0.0034 & -0.2661 & 0.0988 & 0.0439 & $53.54 \%$ \\
\hline $\mathrm{CAR}(+1,+3)$ & 0.0032 & 0.0045 & -0.1164 & 0.1344 & 0.0448 & $46.46 \%$ \\
\hline $\mathrm{CAR}(+3,+5)$ & -0.0037 & -0.0020 & -0.1247 & 0.0663 & 0.0310 & $54.55 \%$ \\
\hline
\end{tabular}

AQ: 16
Note(s): This table shows cumulative abnormal return of different event windows. The symbol *,** and *** denote the significance at the $10 \%, 5 \%$ and $1 \%$ significance level, respectively
Table 5.

Descriptive statistics and significance test of cumulative abnormal return 


\section{IJMF}

Figure 4.

Cumulative average abnormal return for Sample 2

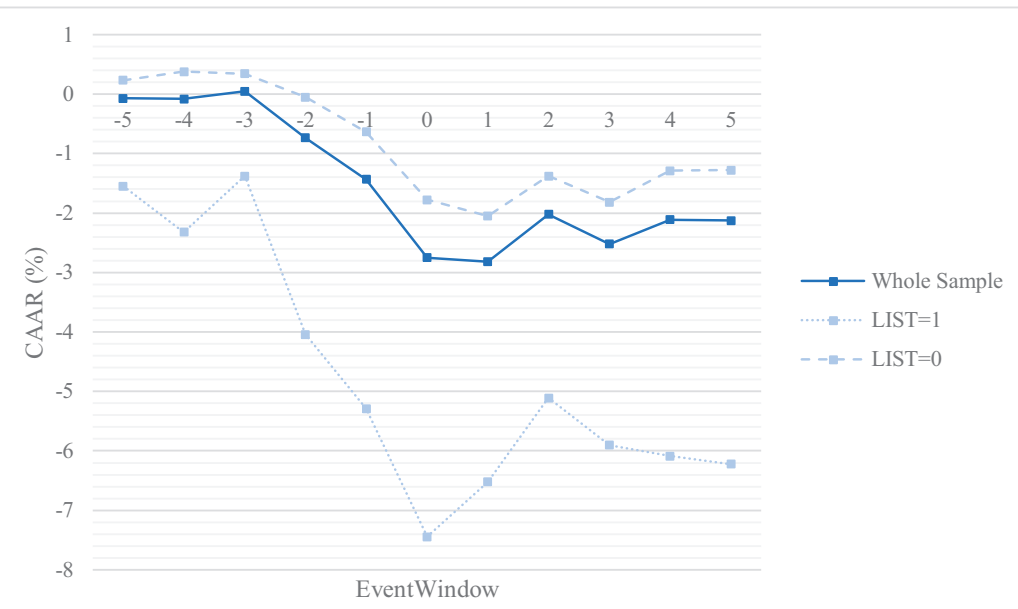

Note(s): The solid line plots the CAAR of the whole sample. The dotted line plots the CAAR of firms that are within ten target industries of the safeguard tariff. The dash line plots the CAAR of firms that are not subject to the tariff imposition. The scale for the $y$-axis is in percentage

date, corresponding to the $1.38 \%$ negative abnormal return observed in Table 1 . A surprising finding is that the cumulative abnormal return of these listed firms rebound after the initiation of the trade war, as the tariff imposition is considered as a negative shock to their stock performances. The possible explanation for the unexpected bounce back could be the undervaluation of Chinese exporting firms by pessimistic investors before the event. Before the initiation of the bilateral trade dispute between the USA and China, the United States government has already imposed several rounds of safeguard tariff on washing machines, solar panels, steel and aluminum. Although China is not the only country subject to these tariff impositions, the increasingly tense trade relation between China and its major exporter could bring about panics and over-pessimism in the Chinese stock market, leading to the undervaluation of Chinese firms that excessively depend on trades with the United States. Once the trade war was eventually launched on March 22, the extent of the influence of safeguard tariff on Chinese exporting firms' falls short the expectation of the over-pessimistic market, inducing the stock return to rebound right after the event date. Another potential reason for the anomaly trend of stock return post-event could be the retaliatory measures imposed by the Chinese government at the event date, which helps to restore the confidence of stock traders in investing in Chinese exporting firms. Several hours after the issuance of the presidential memorandum for safeguard tariff imposition by the United States, the Chinese government proposed to hit back with a 15\%-25\% tariff on a list of 128 American goods worth nearly three billion US dollars once the trade talks break down. The tit-for-tat response from the Chinese government mirrors its intransigent and indomitable stance facing international trade disputes, signaling that the state government will protect domestic exporting companies from potential losses. That is why the abnormal return of firms in the sample surged after the event date when the Chinese government announced its counteraction against the United States. Besides the solid line for the cumulative average abnormal return of the whole sample, we also plot the CAAR for two subsamples that include firms within and out of the targeted industries, respectively, using the dash lines. We note 


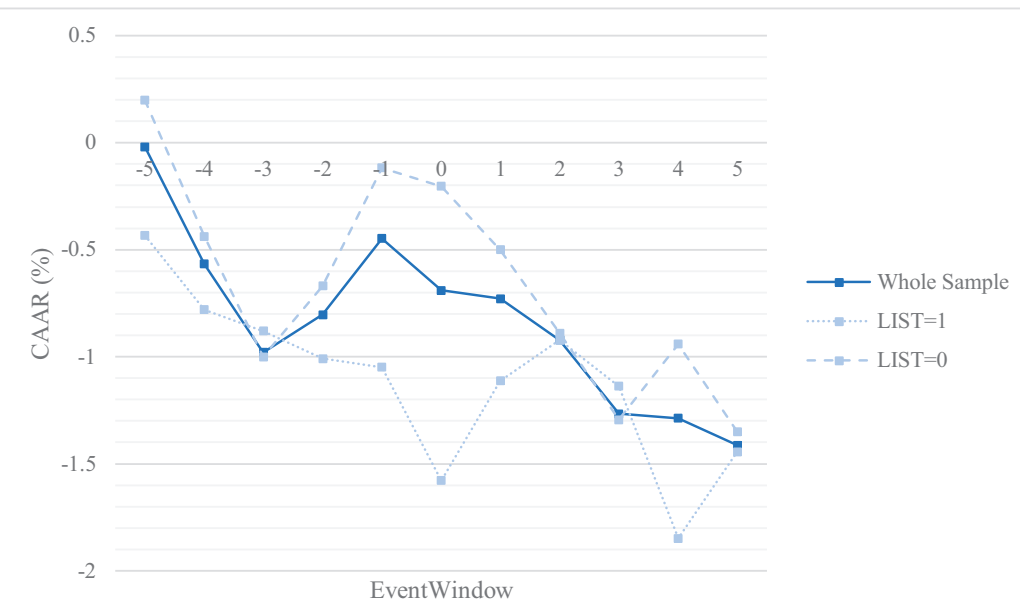

Note(s): The solid line plots the CAAR of the whole sample. The dotted line plots the CAAR of firms that are within ten target industries of the safeguard tariff. The dash line plots the CAAR of firms that are not subject to the tariff imposition. The scale for the $y$-axis is in percentage
Heterogeneous firm-level responses

Figure 5. Cumulative average abnormal return for Sample 3

that stocks on the tariff list experience lower abnormal returns than stocks that are not on the list throughout our event window.

Figure 5 shows that there exists information leakage in the Hong Kong stock market before the initiation of the trade war at the event date. The cumulative average abnormal return starts to plunge from the day -2 and performs its most significant drop at the event date, corresponding to the previous results of $0.78 \%, 0.7$ and $1.32 \%$ negative abnormal return for these three trading days. Information leakage is inevitable in the real world because some agents such as financial analysts and insiders in the listed companies can perceive indications of new information before the information is released to the public. The overreaction of the investors in the Hong Kong stock market is followed by a rebound of stock performances to its fair value post-event. The cumulative abnormal return recovers partially since day +2 , and the extent of the fluctuation decreases over time. Another possible driver for the positive abnormal return after the event date could be the retaliatory tariff proposed by the Chinese government. The stock market tends to respond less severely to the countermeasure than the original trade sanction as the expectation of the tit-for-tat measures gets priced in after the investor perceives the initial information. Moreover, the firms on the list significantly underperform the firms that are not subject to the safeguard tariff throughout our event window.

F6 The solid line in Figure 6 looks almost the same as the solid line in Figure 5 despite some nuances of the magnitude of the fluctuation. The possible explanation could be the overlaps of data between Sample 2 and Sample 4. In all, 55 out of 99 stocks appear in both two samples despite the different criteria in sample selection. The dash and dotted lines of two subsamples show different patterns between Figures 5 and 6, probably due to the difference in the proportion of firms that are on the list in the whole sample. On the contrary, Figure 3 is utterly different from Figure 4, showing the existence of information leakage in the Chinese stock market before the tariff announcement. The cumulative average abnormal return falls sharply from the day -5 to day -3 , bounces back from the day -2 to day -1 and continues 


\section{IJMF}

Figure 6.

Cumulative average abnormal return for Sample 4

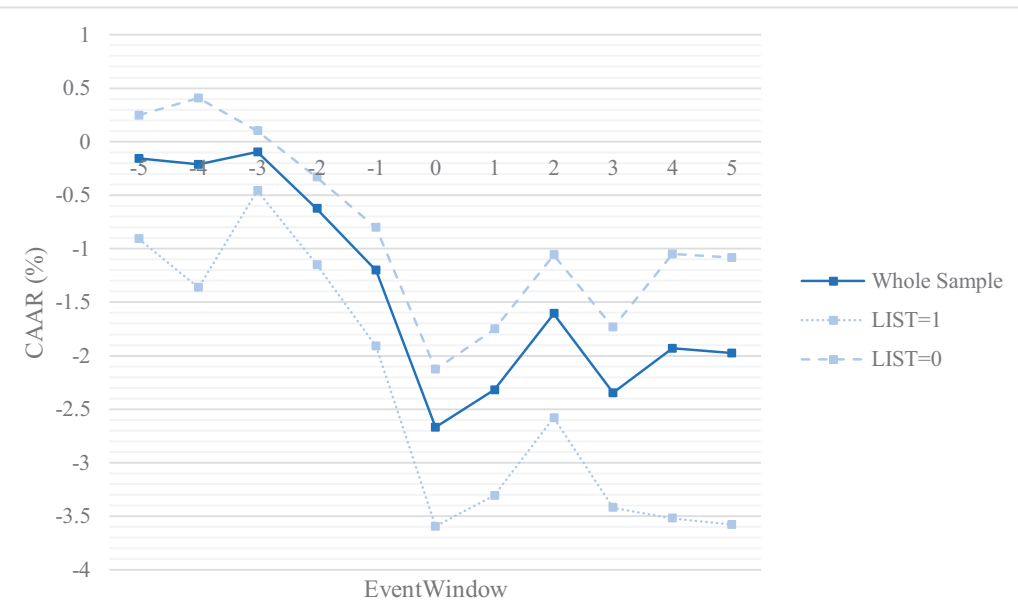

Note(s): The solid line plots the CAAR of the whole sample. The dotted line plots the CAAR of firms that are within ten target industries of the safeguard tariff. The dash line plots the CAAR of firms that are not subject to the tariff imposition. The scale for the $y$-axis is in percentage

falling after that. The stocks that are not subject to the tariff imposition outperform the stocks on the list throughout the event window except at day -3 , day +2 and day +3 .

A brief examination of Table 6 reveals some basic patterns of firm characteristics across samples that could help to explain the heterogeneity in stock performances in response to the tariff announcement. Firms with higher revenue from the United States generally have a larger firm size, longer time for which the firm is listed and less idiosyncratic risk. For stocks listed in Shanghai and Shenzhen Stock Exchanges, firms with higher revenue from the United States also have more state shares in their total number of shares. As the data for state shares are not available in the Hong Kong stock market, we cannot make inferences about the correlation between the firm ownership and other characteristics for $\mathrm{H}$ shares. In terms of stock markets, Hong Kong-listed firms have larger market values, higher unsystematic risk and lower liquidity than China-listed firms.

In addition, we conduct both univariate and multivariate regression analyses in order to detect the heterogeneous firm-level responses to the tariff hike announcement within the event window. The univariate test relies heavily on the assumption that all other factors that affect the dependent variable $y$ are not correlated with the independent variable $x$ included in the regression. This assumption is impractical in most cases. Consequently, we would put more emphasis on the results of the multivariate test by discussing the hypotheses individually. The multivariate regression analysis is more comfortable to interpret, ceteris paribus, because it allows us to explicitly control for the other explanatory variables that affect $y$ simultaneously (see Table 7).

Our first hypothesis for the cross-sectional analysis is that the extent of influence by the tariff announcement on firms in the targeted industries is greater than the extent of influence on firms that are not subject to the safeguard tariff. Based on the coefficients on the independent variable "LIST," we cannot reject the null hypothesis in general. Though all the coefficients are negative, suggesting a greater price drop among stocks of firms that are from the targeted industries, they are statistically insignificant. The results show that for firms whose operational 


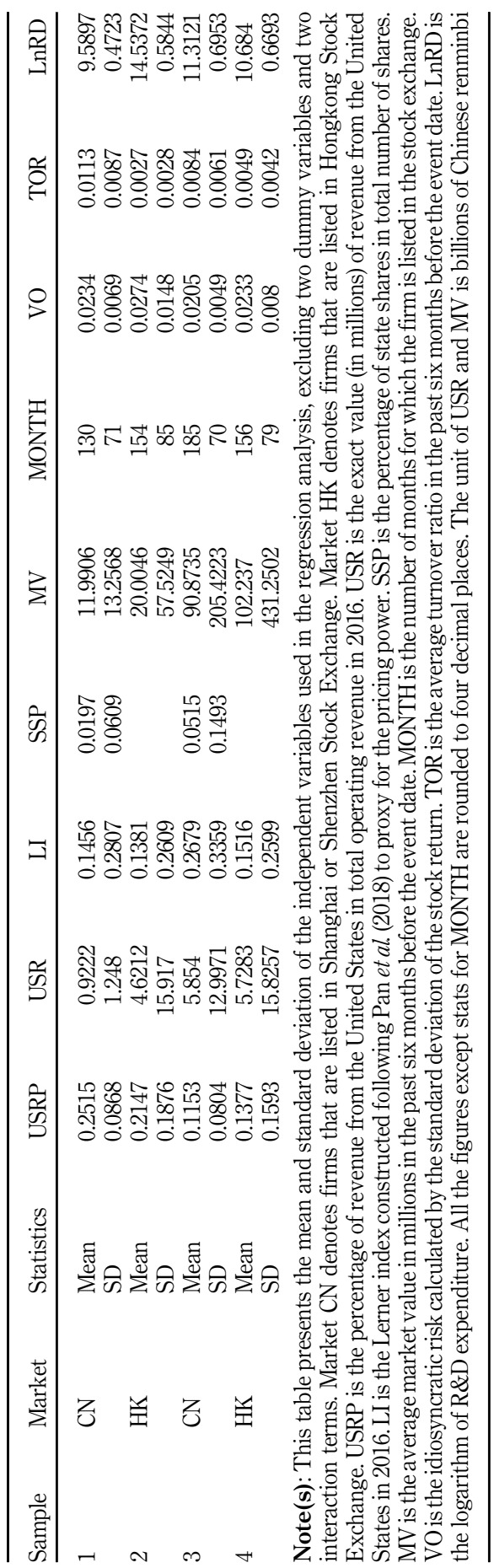

Heterogeneous firm-level responses

Table 6. Summary statistics of independent variables 


IJMF

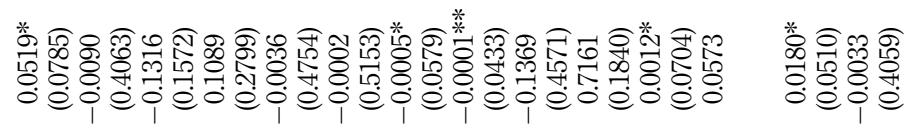

₹

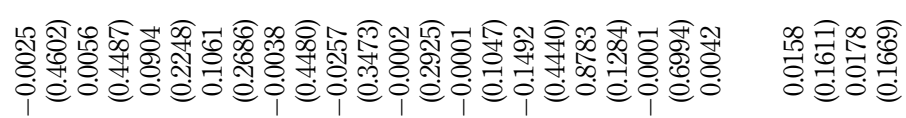

Table 7.

Multivariate regression analysis

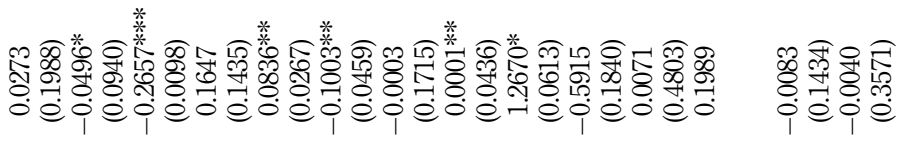

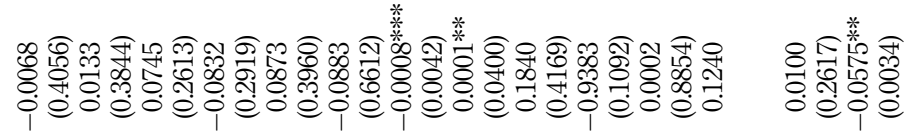

๙

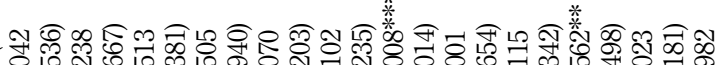

ङ

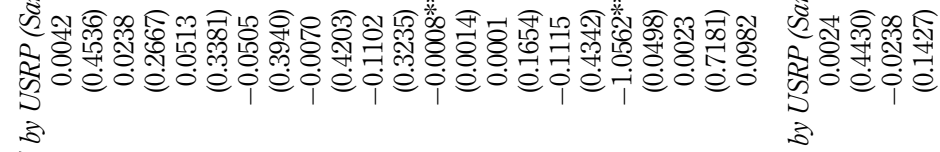
उ.

है ฐँ

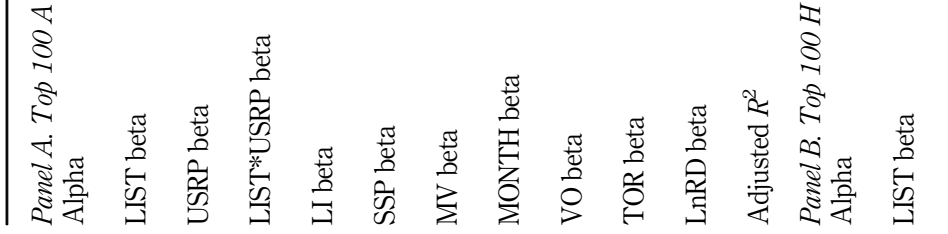

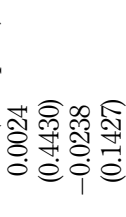
ङ $\frac{\sqrt{2}}{2}$ 


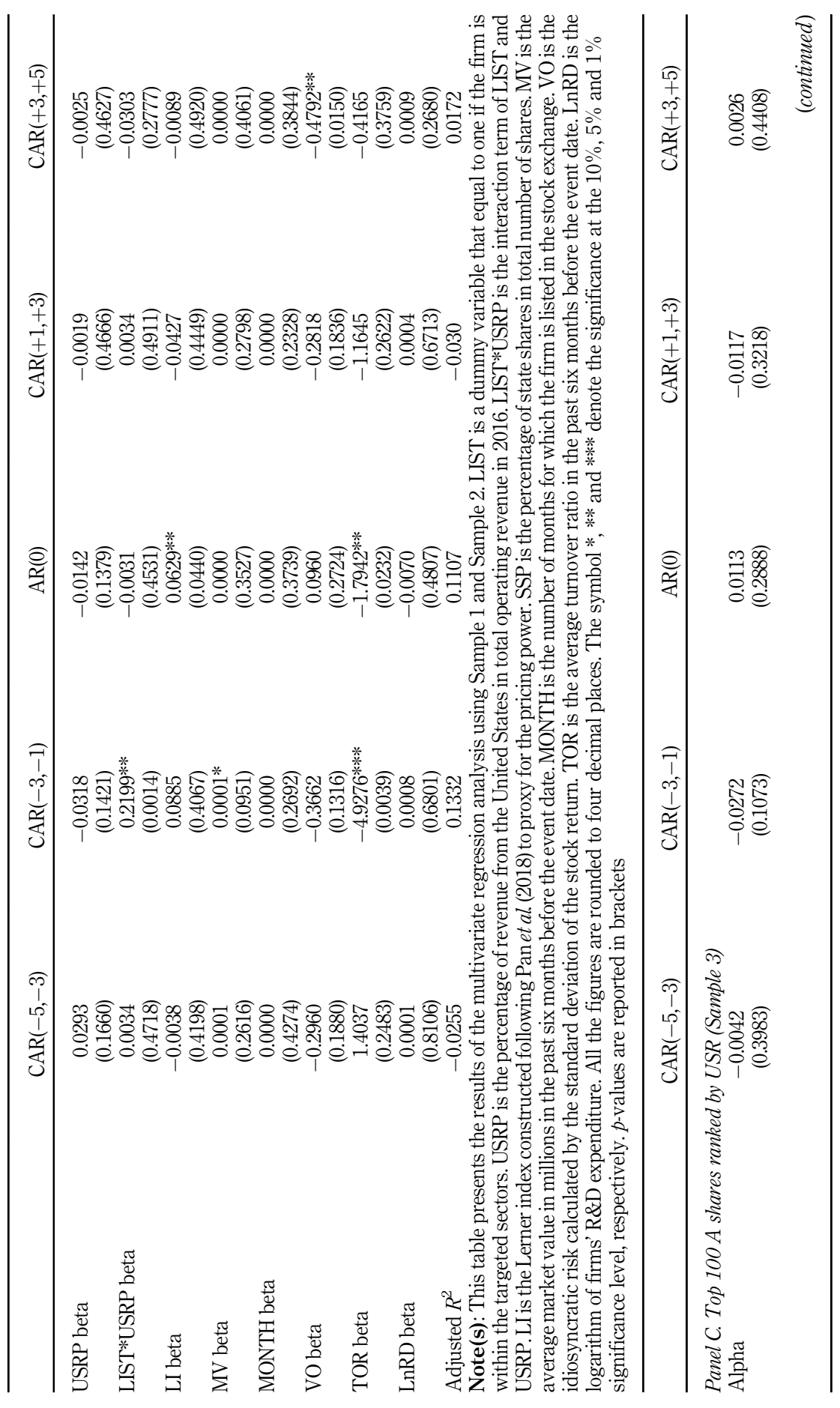

Heterogeneous firm-level responses

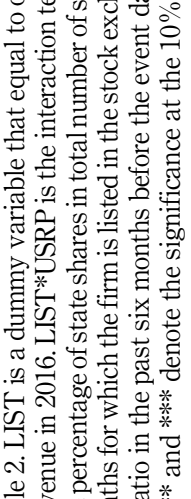

里宾

光

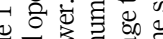
준 \pm on $\#$ क. 曹云示

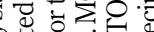

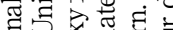

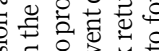

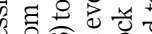

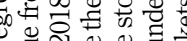
政 政. . 离奇吉 要专 电声要 스류.

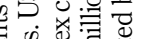
……

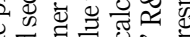

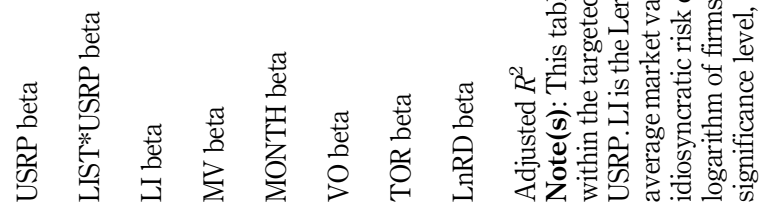

Table 7. 


IJMF
○ी

\section{Table 7.}

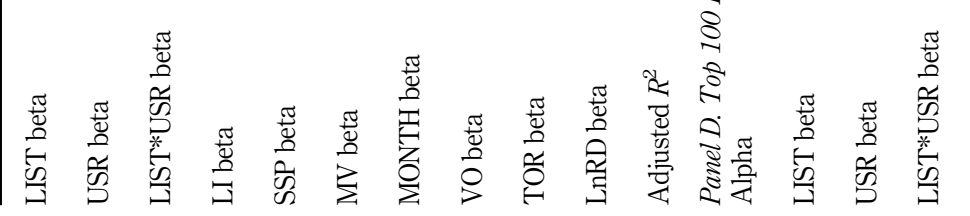

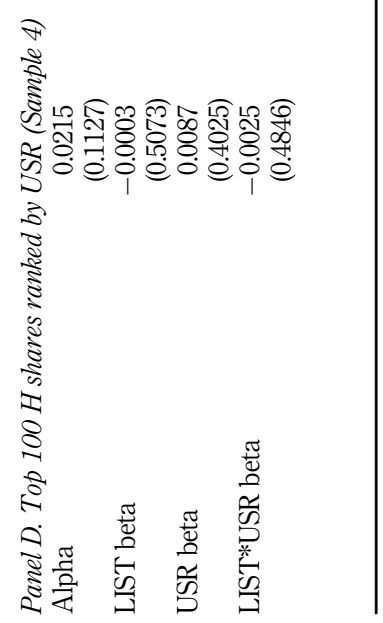




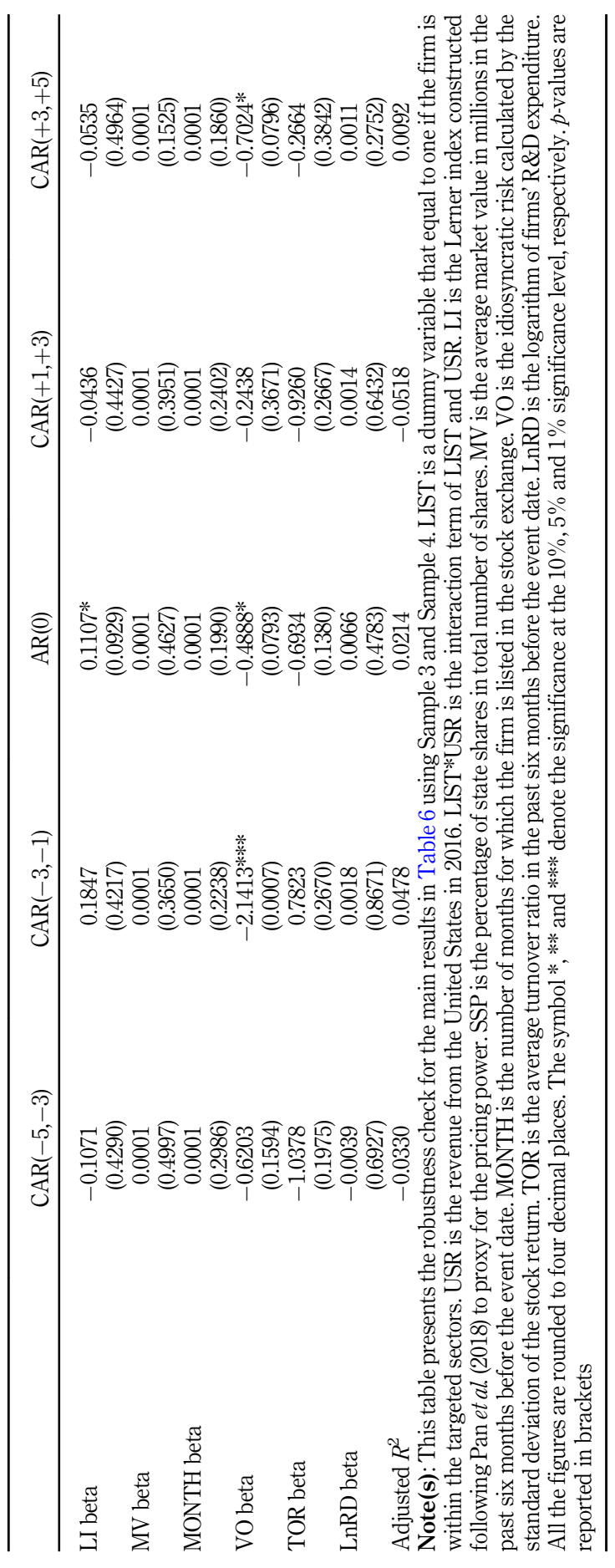

Heterogeneous firm-level responses

Table 7. 
revenues are heavily dependent on the USS, the tariff announcement affects their returns no matter whether they belong to the targeted industries or not. One exception, however, is that for Sample 2 which uses stocks listed in the Hong Kong Stock Exchange, the null hypothesis is rejected at a $5 \%$ significance level for cumulative abnormal return between day -3 and day -1 . Holding other factors fixed, companies that are on the tariff list experience $5.75 \%$ lower CAR($3,-1)$ than companies that are not on the tariff list. The results are in line with our forecast, providing strong statistical evidence for the observation in Figure 5.

The second hypothesis examines the importance of the export dependency of Chinese exporters on the United States to the announcement of tariff sanction. For both Hong Konglisted samples, there is no significant evidence to reject the null hypothesis, as the coefficients on the exporting dependency measures USRP and USP are both statistically insignificant. For the first sample using China-listed stocks, the coefficient of USRP is negative and statistically significant at a $99 \%$ confidence level for $\mathrm{AR}(0)$. When the percentage of US revenue rises by $1 \%$, ceteris paribus, the abnormal return at the event date drops by $0.2657 \%$. For the third sample, the coefficient of USR is negative and statistically significant at a $5 \%$ significance level for abnormal return at day zero. The coefficient indicates that a one million's increase in the USR is accompanied by a $0.0852 \%$ decrease in $\mathrm{AR}(0)$. Hence, firms whose operation or revenue is more dependent on the USA experience a greater price drop on the event day.

Moreover, we add an interaction term of LIST and USRP in order to find the effect of the export dependency on those firms that are in the targeted industries specifically. The coefficient of the interaction term LIST*USRP is expected to have the same negative sign as the coefficient of the USRP but with a more considerable significance. However, we can see that all the coefficients on the interaction terms with $\mathrm{AR}(0)$ as dependent variables are statistically insignificant. Such results again suggest that the tariff announcement affects the US exporting firms equally no matter whether they are targeted or not.

On the contrary, significant and positive coefficients are detected for CAR $(1,3)$ and CAR $(3,5)$ in the third sample, which contains the firms with the highest US exporting revenue. For those stocks that are on the tariff list, there is a strong reversal in stock prices following the tariff announcement. Also combining with findings in Figure 3, we can see that the significance in the coefficient is mainly driven by the fact that while stocks not on the tariff list continue to have a price drop following the announcement, stocks on the list exhibit a reversal.

One interesting finding is that the coefficients of the pricing power proxy LI are all positive, being statistically significant at 5\% levels for Samples 1, 2 and 3, and at 10\% level for Sample 4. Such finding is consistent with our conjecture that firms with greater pricing power will be less affected by the sudden negative announcement.

When we look at the regression results on the control variables, we do not seem to see much obvious pattern. For example, as the data of state shares are not available for $\mathrm{H}$ shares in the Hong Kong stock market, the control variable SSP is excluded in the multivariate regression equation for Sample 2 and Sample 4. Considering the first sample, the coefficient of $\mathrm{SSP}$ is negative and statistically significant at the $10 \%$ significance level, suggesting that firms with $1 \%$ more of state shares in total shares, ceteris paribus, experience $0.1003 \%$ lower abnormal return on the event day. In contrast, the coefficients of SSP from Sample 3 show quite different findings. During the 5-day window before the announcement, firms with greater government ownership seem to have less price drops compared with other firms, indicating the public's confidence in firms with more revenues generating from the USA but heavily owned by the government. But on the event day, firms with different levels of government ownership do not show significant difference in their returns. Regarding the firms' age, measured by MONTH, we can see that while for the Sample 1, firms with longer history is less affected by the announcement on and immediately before the event day, we do not see any obvious effect on other samples. The other control variables VO, TOR and LnRD all show mixed effect across the four samples and the different event windows. 


\section{Conclusion}

This study analyzes the heterogeneous firm-level responses to the first round of the safeguard tariff announced by the Trump administration on March 22, 2018, which triggers yearlong trade disputes between the United States and China. By employing an event study, we show that the tariff announcement has significantly negative impacts on stock performances both before and after the announcement. Our multi-regression results explain the heterogeneity in abnormal return upon the tariff announcement with various firm-level characteristics. For A shares listed in the Shanghai and Shenzhen Stock Exchanges, firms with more revenues from the USA, measured either by absolute values or by relative percentage of their total operational revenues, experience lower abnormal returns at the event date. However, such impact does not show any significant difference between firms that are on the targeted tariff list and firms that are not on the list. The findings only apply to the firms listed in Shanghai and Shenzhen Stock Exchanges. For H shares that are listed in Hong Kong Stock Exchange, we do not find similar results. However, we do find that for all the firms across the four samples, pricing power of the firm plays a significant role in alleviating the negative market impact. The mixed results obtained from the regression analysis across samples are probably due to the difference in stock market efficiency, the composition of stock investors and their

AQ: 12 trade behaviors between Shanghai-Shenzhen and Hong Kong stock markets.

\section{Notes}

1. For the robustness test, we also use the exact value of the revenue generated from the USA as another measure for the export dependency, and the results are available upon request.

2. The list of firms selected are based on Wang and $\mathrm{Li}$ (2018) who generate the list of top 100 Chinese listed companies according to the proportion of revenue generated from the USA in their total operating revenue and the exact value of revenue from the USA, respectively.

\section{References}

Ang, A., Hodrick, R.J., Xing, Y. and Zhang, X. (2006), "The cross-section of volatility and expected returns”, The Journal of Finance, Vol. 61 No. 1, pp. 259-299, doi: 10.1111/j.1540-6261.2006.00836.x.

Crowley, M.A., Meng, N. and Song, H. (2018), "Policy shocks and stock market returns: evidence from Chinese solar panels", Journal of the Japanese and International Economics, Vol. 51, pp. 148-169, doi: 10.1016/j.jjie.2019.02.006.

Da, Z., Engelberg, J. and Gao, P. (2011), “In search of attention”, The Journal of Finance, Vol. 66 No. 5, pp. 1461-1499.

Gumanti, T.A., Savitri, E., Nisa, N.W. and Utami, E.S. (2018), "Event study on the crash of Airasia plane: a study on travel and leisure companies listed at Malaysian stock market", Jurnal Akuntansi dan Keuangan, Vol. 20 No. 1, pp. 20-26, doi: 10.9744/jak.20.1.20-26.

Hartigan, J.C., Perry, P.R. and Kamma, S. (1986), "The value of administered protection: a capital market approach", The Review of Economics and Statistics, Vol. 68 No. 4, pp. 610-617, doi: 2307/1924520.

Huang, Y., Lin, C., Liu, S. and Tang, H. (2018), "Trade linkages and firm value: evidence from the 2018 US-China "trade war", The Graduate Institute of International Studies, IHEID Working Papers 11-2018, Economics Section.

Hughes, J.S., Lenway, S.A. and Rayburn, J.D. (1997), "Stock price effects of US trade policy responses to Japanese trading practices in semi-conductors", Canadian Journal of Economics, Vol. 30 No. 4, pp. 922-942, doi: 10.2307/136278.

Lenway, S., Rehbein, K. and Starks, L. (1990), "The impact of protectionism on firm wealth: the experience of the steel industry", Southern Economic Journal, Vol. 56 No. 4, pp. 1079-1093, doi: 10.2307/1059893. 
Liebman, B.H. and Tomlin, K.M. (2008), "Safeguards and retaliatory threats", The Journal of Law and Economics, Vol. 51 No. 2, pp. 351-376, available at: https://www.jstor.org/stable/10.1086/589662.

Mackinlay, A.C. (1997), "Event studies in economics and finance", Journal of Economic Literature, Vol. 35 No. 1, pp. 13-39.

Merton, R.C. (1987), "A simple model of capital market equilibrium with incomplete information”, The Journal of Finance, Vol. 42 No. 3, pp. 483-510, doi: 10.1111/j.1540-6261.1987.tb04565.x.

Miyajima, H. and Yafeh, Y. (2007), “Japan's banking crisis: an event-study perspective”, Journal of Banking and Finance, Vol. 31 No. 9, pp. 2866-2885, doi: 10.1016/j.jbankfin.2007.03.006.

Qu, Z., Liu, X. and He, S. (2019), "Abnormal returns and idiosyncratic volatility puzzle: evidence from the Chinese stock market”, Emerging Markets Finance and Trade, Vol. 55 No. 5, pp. 1184-1198, doi: 10.1080/1540496X.2018.1468249.

Wang, Y.C. and Chou, R.K. (2018), "The impact of share pledging regulations on stock trading and firm valuation”, Journal of Banking and Finance, Vol. 89, pp. 1-13, doi: 10.1016/j.jbankfin.2018.01.016.

Wang, H. and Li, Q. (2018), Sino-US Trade War: Possible Influences and Responses, China International Capital Corporation, Beijing.

Wanger, A.F., Zeckhauser, R.J. and Ziegler, A. (2017), "Company stock price reactions to the 2016 election shock: Trump, taxes, and trade", Journal of Financial Economics, Vol. 130 No. 2, pp. 428-451, doi: 10.1016/j.jfineco.2018.06.013.

Yang, M. and He, Y. (2018), "How does the stock market react to financial innovation regulations?", in press, Finance Research Letters. doi: 10.1016/j.frl.2018.10.006.

Zhao, X., Fan, Y., Fang, M. and Hua, Z. (2018), "Do environmental regulations undermine energy firm performance? An empirical analysis from China's stock market”, Energy Research and Social Science, Vol. 40, pp. 220-231, available at: https:/www.sciencedirect.com/science/article/pii/ S2214629618301877.

\section{Further reading}

Baggs, J. and Brander, J.A. (2006), "Trade liberalization, profitability, and financial leverage”, Journal of International Business Studies, Vol. 37 No. 2, pp. 196-211, doi: 10.1057/palgrave.jibs.8400183.

Banz, R.W. (1981), "The relationship between return and market value of common stocks”, Journal of Financial Economics, Vol. 9 No. 1, pp. 3-18, doi: 10.1016/0304-405X(81)90018-0.

Breinlich, H. (2014), "Heterogeneous firm-level responses to trade liberalization: a test using stock price reactions", Journal of International Economics, Vol. 93 No. 2, pp. 270-285, doi: 10.1016/j. jinteco.2014.04.002.

Greenland, A., Ion, M., Lopresti, J. and Schott, P.K. (2019), "Using equity market reactions to infer exposure to trade liberalization", available at: http://faculty.som.yale.edu/peterschott/files/ research/papers/stock_055.pdf.

Moser, C. and Rose, A.K. (2014), "Who benefits from regional trade agreements? The view from the stock market”, European Economic Review, Vol. 68, pp. 31-47, doi: 10.1016/j.euroecorev.2014.01.012.

Thompson, A.J. (1993), "The anticipated sectoral adjustment to the Canada - United States free trade agreement: an event study analysis", Canadian Journal of Economics, Vol. 26 No. 2, pp. 253-271, doi: $10.2307 / 135906$.

\section{Corresponding author}

Min Bai can be contacted at: mbai@waikato.ac.nz

For instructions on how to order reprints of this article, please visit our website:

www.emeraldgrouppublishing.com/licensing/reprints.htm

Or contact us for further details: permissions@emeraldinsight.com 


\section{Heterogeneous Firm-level Responses to the}

US 2018 Tariff Announcement

Qin, Y

2020-12-07

22/04/2023 - Downloaded from MASSEY RESEARCH ONLINE 